\title{
The Role of Social Media on Sexual Activity in Adolescents
}

\author{
Wulan Rahmadhani ${ }^{1 *}$, Retno Tristanti ${ }^{1}$, Reni Komariyah ${ }^{1}$, Adinda Putri Sari Dewi ${ }^{1}$, Eka \\ Novyriana ${ }^{1}$ \\ ${ }^{1}$ Faculty of Health, Universitas Muhammadiyah Gombong, Indonesia
}

*Corresponding author : wulannnnn02@gmail.com

ARTICLE INFO

Article history

Received 12/01/2022

Revised 20/01/2022

Accepted 26/01/2022

Keywords

Social Media

Sexual Activity

Adolescents

\begin{abstract}
Background: Adolescence is a period of rapid growth both physical, psychological and intellectual, including the proficiency and need for the internet. One of the purposes of internet use for teenagers is to access social media. There are various negative behaviors that arise in adolescents due to the use of technology that makes it easier for internet access Such behaviors include sexual behavior. Adolescent sexual problems are a global research issue, because although biologically adolescents are able to reproduce, sexual behavior among adolescents can result in a variety of long-term negative consequences. The purpose of this study is to analyze and summarize the results of one another's research on the role of social media on sexual activity in adolescents. Results: From all journals that have been reviewed and taken as literature obtained that there is a relationship between the role of social media to sexual activity in adolescents. Conclusion: There is a relationship between the role of social media in sexual activity in adolescents.
\end{abstract}

\section{Introduction}

Entering the era of increasingly advanced technology undeniably affects human life. Increasingly sophisticated technology makes things very easy [1]. The use of email, short massage, mobile phones, various social media, and instant messaging, is now recognized by various circles [2]. Various social networking applications have many conveniences so that everyone can communicate easily with others without being limited to space and time [3]. It has various positive and negative aspect [4]. The positive aspect that happens, a person will easily interact with everyone in the world easily and cheaply [5]. But it cannot be denied that various negative things will also occur when everyone uses these facilities in social interaction [3]. Internet users in Indonesia are 73 million. They access social media [6].

There are various negative behaviors that arise in adolescents due to the use of technology that makes it easier for internet access. These behaviors include sexual behavior [2]. Adolescent sexual problems are a global research issue, because although biologically adolescents are able to reproduce, sexual behavior among adolescents can result in a variety of long-term negative consequences [7]. While many opinions say that the symptoms of sexual behavior are only symptoms of developed countries as a result of modernization or westernization [8]. But that's not always the case because a survey in some developing countries showed that $46 \%$ of young women (14-17 years old) and $66.2 \%$ of young men in Liberia are already in love and in Nigeria already infested is $38 \%$ for young women and $57.3 \%$ for young men (15-19 years) [1]. The increasing sexual interest of adolescents encourages adolescents to commit sexual behavior that gives rise to various sexual problems in adolescents [9].

A study says that teenagers aged 13-19 years once sent naked photos to others [10]. Another study reported that $28 \%$ of teens have ever received or sent pornographic photos. Based on the above background, the authors are interested in learning more about social media's relationship 
to sexual activity in adolescents [9]. Based on the background above, the author is interested in studying more about the relationship of social media to sexual activity in adolescents.

\section{Materials and Method}

The method used is literature review. In the first stage, it begins by searching for articles using PubMed and Google Scholar. The keywords used in the search for articles are social media, sexual activity, adolescents. The articles obtained will be reviewed to obtain articles that meet the predetermined criteria. The inclusion criteria in the search for articles were chosen based on the year of publication, namely the range of 2017-2021 where the subject was adolescents. The exclusion criteria at the time of the article search were selected according to the research variables, the variables were not compared with other variables. The search was carried out according to keywords and found articles that were close to 25 Selection of subsequent articles was carried out based on inclusion and exclusion criteria which resulted in 20 articles being reviewed. The journals that have been found are then specified according to the inclusion criteria and exclusion criteria, namely IC1: journal published, IC2: journal published in 2017-2021, IC3: type of quantitative research, IC4: non-duplicate journal published on Google scholar.

After conforming to IC1-IC4, only 15 articles were left. Then IC5 was selected based on the compatibility of article titles and abstracts with the aim of this literature review, which is to have the main content investigating the events of the role of media social on sexual activity in adolescents and only 5 journals were selected that will be analyzed. The journals that have been found are then specified according to the inclusion criteria and exclusion criteria, namely IC1: journal published, IC2: journal published in 2017-2021, IC3: type of quantitative research, IC4: non-duplicate journal published on Google scholar.

The strategy in searching the literature is attached to

Figure 1

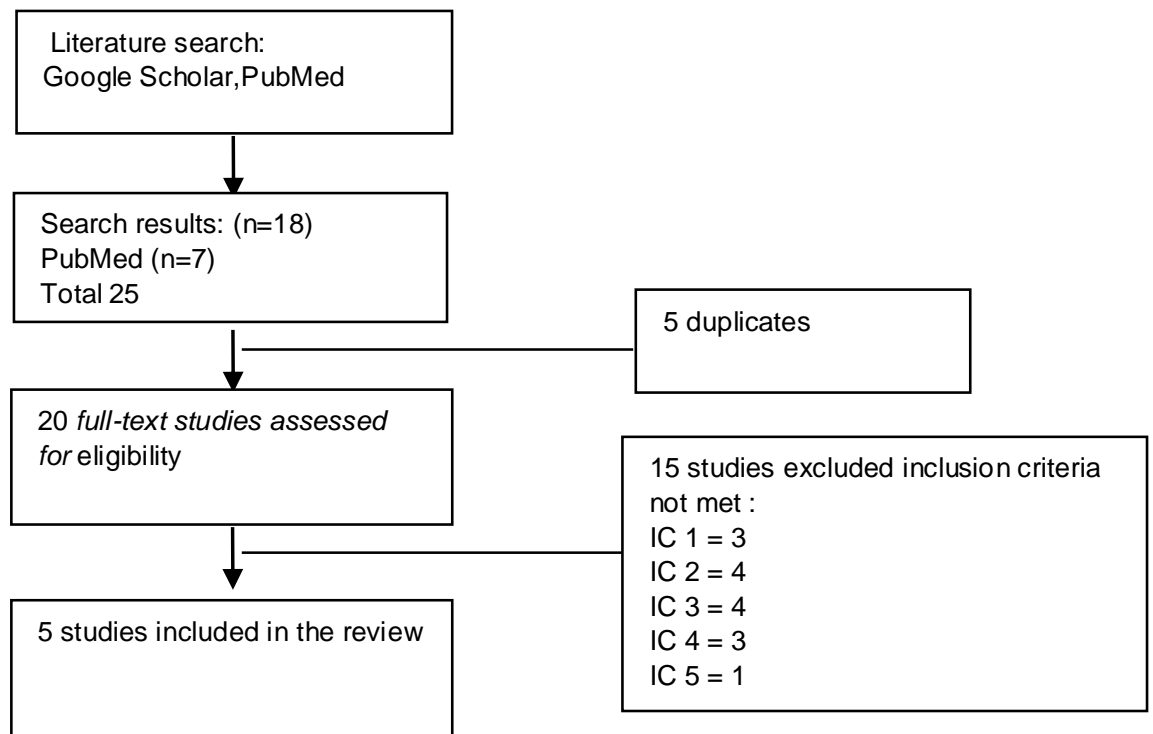

Figure 1. Flow of literature review 


\section{Results and Discussion}

\subsection{Results}

The author explores the journal through a database of journals based on the conformity of criteria that have been defined and keywords that have been determinedn.

Table 1. Literature review results

\begin{tabular}{|c|c|c|c|c|c|c|}
\hline $\begin{array}{l}\text { Author's } \\
\text { name }\end{array}$ & Heading & Method & $\begin{array}{l}\text { Sampling } \\
\text { techniques }\end{array}$ & Sample & $\begin{array}{c}\text { Data } \\
\text { analysis }\end{array}$ & Research results \\
\hline $\begin{array}{l}\text { Malati, } \\
\text { D. } \\
\text { (2019) } \\
\text { Indonesian }\end{array}$ & $\begin{array}{l}\text { related to } \\
\text { social media } \\
\text { use and } \\
\text { peer } \\
\text { influence } \\
\text { with } \\
\text { adolescent } \\
\text { sexual }\end{array}$ & $\begin{array}{l}\text { Cross } \\
\text { Sectional }\end{array}$ & $\begin{array}{l}\text { Accidental } \\
\text { sampling }\end{array}$ & $\begin{array}{l}189 \\
\text { people } \\
\text { (11th- } \\
17 \text { th) }\end{array}$ & Bivariate & $\begin{array}{l}\mathrm{P} \text { value } 0.000 \text { with an } \\
\text { OR value of } 1.953 \\
\text { indicating that there } \\
\text { is a significant } \\
\text { association between } \\
\text { social media use and } \\
\text { risky sexual behavior }\end{array}$ \\
\hline
\end{tabular}

$\begin{array}{lllll}\text { Elpira } & \text { Mass and } & \text { Cross } & \text { Accidental } & 345 \\ \text { Asmin } & \text { social media } & \text { Sectional } & \text { sampling } & 12 \text { th- } \\ \text { Josepina } & \text { use of } & & & 16 \text { th } \\ \text { Mainase } & \text { adolescent } & & \\ \text { (2020) } & \text { sexual } & & \\ \text { Indonesian } & \text { behavior } & & \end{array}$

exist influence use of mass media towards Adolescent sexual behavior in high school science health pasapua ambon value $p$ $=0.0001$

\begin{tabular}{|c|c|c|c|c|c|c|}
\hline $\begin{array}{l}\text { Dina, et al } \\
\text { (2017) } \\
\text { (Newyork) }\end{array}$ & $\begin{array}{l}\text { Social } \\
\text { Media Use } \\
\& \text { its } \\
\text { Association } \\
\text { with Sexual } \\
\text { Risk and } \\
\text { Parental } \\
\text { Monitoring } \\
\text { to } \\
\text { Adolescent } \\
\text { Population }\end{array}$ & $\begin{array}{l}\text { Study Site } \\
\& \\
\text { Enrollment }\end{array}$ & $\begin{array}{l}\text { Accidental } \\
\text { sampling }\end{array}$ & $\begin{array}{l}459 \\
12 \text { th- } \\
17 \text { th }\end{array}$ & Bivariate & $\begin{array}{l}\text { The use of social } \\
\text { media has the } \\
\text { opportunity to } \\
\text { perform sexual } \\
\text { activities such as }\end{array}$ \\
\hline
\end{tabular}

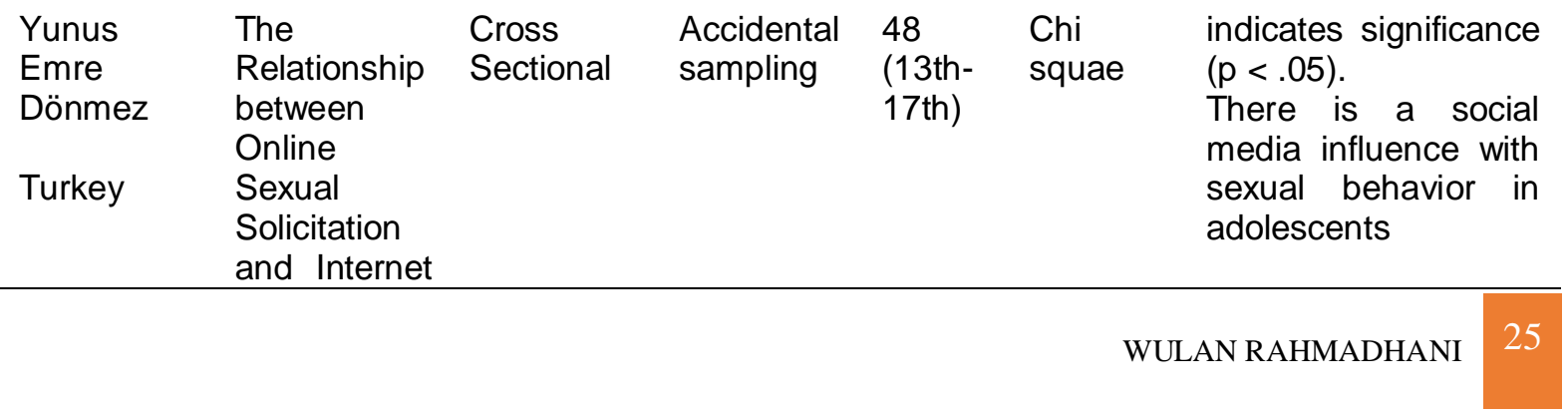


Addiction in

Adolescents

\begin{tabular}{|c|c|c|c|c|c|c|}
\hline $\begin{array}{l}\text { Pizzol } \\
\text { Damiano*, } \\
\text { B. A. and }\end{array}$ & $\begin{array}{l}\text { Adolescents } \\
\& \text { web porn: } \\
\text { a new era of }\end{array}$ & $\begin{array}{l}\text { Cross } \\
\text { Sectional }\end{array}$ & $\begin{array}{l}\text { Accidental } \\
\text { sampling }\end{array}$ & $\begin{array}{l}1565 \\
12 \text { th } \\
17 \text { th }\end{array}$ & $\begin{array}{l}\text { Chi } \\
\text { square }\end{array}$ & $\begin{array}{l}\text { Almost every day } \\
\text { teenagers access } \\
\text { pornography } 1163\end{array}$ \\
\hline $\begin{array}{l}\text { F.C. } \\
(2017) .\end{array}$ & sexuality. & & & & & $\begin{array}{lr}(77.9 \%) & 686 \\
(59 \%) .255 & (21.9 \%) \\
\text { defined it as a habit. }\end{array}$ \\
\hline Italian & & & & & & $\begin{array}{l}116(10 \%) \text { interes } \\
\text { and the remainin } \\
106 \\
(9.1 \%) \text { said addiction }\end{array}$ \\
\hline
\end{tabular}

\subsection{Discussion}

Adolescence is a phase of rapid physical, psychological, and intellectual growth. This can cause teenagers to have traits such as great curiosity, love adventure, and be willing to accept challenges [3]. On the other hand, the availability of means to fulfill desires in adolescents gives rise to inner conflict [11]. If decisions taken inappropriately can cause adolescents to behave risky, for example there is risky sexual behavior. This behavior causes adolescents to have to bear the consequences of physical and psychosocial health problems [12].

Adolescent behavior is influenced by the internal factors of adolescents (knowledge, attitudes and personality) as well as external factors of adolescents (the environment in which he is located) but usually external factors are more influential [2]. Especially in the era of globalization, the social environment is very dynamic and open. One that is brought in this dynamic is the change in the lifestyle of teenagers [12]. The combination of the typical adolescent developmental age (learning age) with the dynamic social and cultural environment today, makes adolescents enter various "world" environments that are often not properly understood by previous generations, including their own parents [13]. One external factor that is close to teenagers is the internet [2].

This fact shows, respondents whose heavy use of social media is more likely to perform risky sexual behaviors. Thus, a pattern of relationships between social media use and sexual behavior are formed [5]. Teenage people can't be separated from social media and mobile phones. If this is not done wisely by teenagers then all the information accessed through social media or the internet they do not filter anymore [3]

On the internet or social media various information can be accessed including information that can cause bad effects for its users, not to mention a lot of information published on the internet but is hoax [14]. Adolescent curiosity about reproductive health or about sexuality if they do not get answers from those closest to them such as family or parents, then they will find out through mass media, namely the internet [3].The incorrect information they get will be remembered and imitated at any time. This is what adds to the complexity of the problem of risky sexual behavior among adolescents because the media and trigger factors are increasingly accessible and obtained [1].

In the study $p$ value of 0.004 means that there is a significant relationship between exposure to information media and sexual behavior[14] The result of odds ratio (OR) of $95 \% \mathrm{Cl}=2,625$ $(1,393-4,947)$ means that respondents who have been exposed to media information about sexual behavior are 2.6 times more likely to be at risk of sex behavior than respondents who are exposed to high levels. Based on the results of statistical analysis showing mass media is associated with adolescent sexual behavior with a value ( $p$ value 0.011 ).

Since 2012, Facebook has become a favorite social media of American teenagers. Other social media that are often accessed by teenagers are Instagram, Snapchat, Twitter. This media media is one of the factors of teenagers exposed to pornography [15].

Research shows that social media affects teens who engage in romantic relationships. Social media is used to monitor couples, being aggressive. Most researchers who study sexual media 
focus on the negative effects of media.[2]. Accessing pornographic sites is very easy to do through the internet. Internet use can be done anywhere. [8]. Pornographic sites provided by the internet ranging from images, movies, even live cameras. The goal of teens accessing pornographic sites is to seek information on sexual topics, pornography consumption, detailed desire satisfaction, seek sexual partners, and purchase sexual support. The impact of accessing pornographic sites is addiction, promiscuity, loss of mediation and sexting habits, and paraphilic behavior.

\section{Conclusion}

Based on the results of the analysis of various articles that have been obtained, it can be concluded that there is a relationship that is meaning between social media and sexual behavior in adolescents. The advice that the author can give is expected to further tighten supervision of adolescents, especially parents in the use of social media used, and more increase positive and beneficial activities for teenagers so that teenagers are preoccupied with useful things such as activities in the field of religion or sports. More counseling about reproductive health and adolescent behavior, as well as good parenting patterns for adolescents

\section{References}

[1] L. M and Cookingham, "The impact of social media on the sexual and social wellness of adolescents," J. Pediatr. Adolesc. Gynecol., vol. 3, no. 1, 2014.

[2] D. Malati, "Hubungan Penggunaan Media Sosial dan pengaruh teman sebaya dengan perilaku seksual remaja," J. Kesehat. Masy., vol. 3, no. 1, pp. 24-34, 2019.

[3] Indrijati and Herdina, "Penggunaan internet dan perilaku seksual remaja.," Pros. Temu IIm., vol. 3, no. 1, pp. 44-51, 2018.

[4] W. Rahmadhani, "Pembentukan posyandu remaja di Desa Bejiruyung, Kecamatan Sempor Kabupaten Kebumen," J. Inov. ABDIMAS KEBIDANAN, 2021, doi: 10.32536/jiak.v1i2.169.

[5] Elpira Josepina, "Penggunaan Media massa dan social terhadap perilaku seksual remaja," J. Molucca Medica, vol. 13, no. 1, pp. 24-28, 2020.

[6] Kominfo RI, "Pengguna Internet di Indonesia Capai 82 Juta. Kementrian Komunikasi dan Informatika Republik Indonesia," Jakarta, 2015.

[7] W. Rahmadhani and A. D. Asti, "PENINGKATAN KESEHATAN REPRODUKSI REMAJA MELALUI PENDAMPINGAN KELOMPOK TERAPEUTIK DI DESA INDROSARI, KECAMATAN BULUS PESANTREN, KEBUMEN," J. EMPATI (Edukasi Masyarakat, Pengabdi. dan Bakti), vol. 1, no. 1, p. 51, 2020, doi: 10.26753/empati.v1i1.425.

[8] W. Rahmadhani and W. Laohasiriwong, "Gender of baby and postpartum depression among adolescent mothers in central Java, Indonesia," Int J Child Adolesc Heal., 2020.

[9] M. M. Dina L. Romo, MD, Chelsea Garnett, MD, Alayna P. Younger, MPH, Melissa S. Stockwell, MD, MPH, Karen Soren, MD, Marina Catallozzi, MD, MSCE, Natalie Neu, "Social Media Use and its Association with Sexual Risk and Parental Monitoring among a Primarily Hispanic Adolescent Population," J. Pediatr. Adolesc. Gynecol., 2017.

[10] W. Rahmadhani and W. Laohasiriwong, "Gender of baby and postpartum depression among adolescent mothers in central Java, Indonesia," Int. J. Child Adolesc. Heal., 2020.

[11] W. Rahmadhani, "KNOWLEDGE OF POSTPARTUM MOTHERS ON POSTPARTUM CARE IN HEALTHCARE CENTERS IN KEBUMEN," J. IIm. Kesehat. Keperawatan, 2020, doi: $10.26753 /$ jikk.v16i1.379.

[12] L. M. and Cookingham, "The impact of social media on the sexual and social wellness of adolescents," J. Pediatr. Adolesc., vol. 3, no. 1, 2014.

[13] W. Rahmadhani, J. Suyanto, T. K. Soe, and S. Mutoharoh, "The Relationship Between Husband Support and Behavior of Pregnant Teenagers to Face Pregnancy During the Covid-19 Pandemic in Gombong, Kebumen, Indonesia," Dis. Prev. Public Heal. J., 2021, doi: $10.12928 /$ dpphj.v15i2.4413.

[14] F. Naibabo, "Faktor-faktor yang berhubungan dengan perilaku seksual remaja," J. Sos. dan Humanit., vol. 2, no. 6, pp. 214-220, 2021.

[15] W. Rahmadhani and A. D. Asti, "Peningkatan Kesehatan Reproduksi Remaja Melalui Pendampingan Kelompok Terapeutik Di Desa Indrosari, Kecamatan Bulus Pesantren, Kebumen," J. EMPATI (Edukasi Masyarakat, Pengabdi. dan Bakti), 2020, doi: 10.26753/empati.v1i1.425. 